\title{
EDITORIAL
}

\section{Imagens e identidades em discursos midiáticos}

Em seu segundo número, a revista RUMORES traz temáticas diversas que constroem, cada uma a seu modo, possíveis articulações entre os estudos de linguagem e as práticas midiáticas. Nesta edição, os artigos de nossos colaboradores revelam formulações a partir de inquietações comuns: a relação entre perspectivas teóricas e objetos empíricos relativos ao campo da comunicação. Cada autor, portanto, fala de um lugar específico para delinear, a partir de seu trajeto, um campo de estudos multifacetado.

Guilherme Atem procura correlacionar as principais idéias de Marshall McLuhan e Todd Gitlin a respeito da cultura audiovisual, promovida pelas mídias. Inserida no contexto do Capitalismo Semiótico (Semiocapitalismo), a cultura midiatizada pode ser pensada como "forma", mais do que como "conteúdo". Os fluxos ou torrentes audiovisuais nos embalam cotidianamente, e isso traz certas reconfigurações subjetivas. Hoje, comunicar é mais importante do que os fatos comunicados. O objetivo do artigo é ensaiar questionamentos sobre a "forma-mídia", ou "império dos significantes", aspecto central nas obras desses dois autores.

Partindo de aproximações entre a ciência da informação e os estudos de recepção, Marilda Inez de Lara e Fátima Tálamo propõem a integração da categoria da recepção no processo documentário através da noção de interação, substituindo a idéia de usuário ideal pela de sujeito social. Por ainda não responderem integralmente às questões do acesso à informação semântica, as tecnologias da informação e da comunicação tornam pertinentes os investimentos em metodologias de organização prévia da informação. Dessa forma, emerge a importância da categoria da recepção nos procedimentos documentários, compreendendo-a no âmbito da circulação social da informação e do conhecimento.

Avançando nas reflexões sobre as mídias e suas relações com a produção de sentidos, o artigo de Sandra Fischer trata do tema das imagens presentes em campanhas publicitárias de moda e de marcas de roupas. Tais imagens, tendendo cada vez mais à hibridização e ao pretenso desvio de foco, esmaecem a imagem do produto roupa propriamente dito para enfatizar imagens que carregam conceitos e modos de se dar a ver e de se colocar no mundo específicos e atinentes ao universo identitário com os quais as marcas pretendem se associar. Partindo de tais evidências e à luz de pressupostos teóricos que englobam noções ampliadas de hibridização e o conceito de carnavalização bakhtiniano, o artigo desenvolve reflexões para um estudo comparativo entre duas peças integrantes de campanhas veiculadas pelas griffes de roupas e acessórios Forum e Diesel.

Ainda no campo da produção imagética, o artigo de Luiz Vadico tem como eixo temático uma análise do filme La Vie et la Passion de Jesus Christ, dirigido por Ferdinand, produzido entre os anos de 1902 e 1905 , e conhecido por Paixão da Pathé, utilizando como elemento de comparação alguns fotogramas da Paixão da 
Gaumont, dirigida por Alice Guy em 1903. O trabalho comparativo visa demonstrar como algumas cenas de ambos os filmes são realizadas tendo em vista a finalidade de serem imagens puramente ornamentais, e que ao invés de significarem a representação de hierofanias, como poderia parecer num primeiro momento, são esvaziadas de qualquer significado religioso e descoladas da narrativa, aparecendo, assim, como um elemento puramente estético.

Estendendo os estudos sobre audiovisual, tema recorrente nesta edição, ao tratar das trocas simbólicas que aconteceram entre mídias, linguagens e países, o artigo de Cristina Costa toma como exemplo a peça $A$ Severa, do autor português Júlio Dantas, levantando as influências que a protagonista feminina possa ter tido na construção de heroínas das telenovelas brasileiras. Para estabelecer tais relações, apresenta o Arquivo Miroel Silveira, composto pelos processos da censura prévia ao teatro exercida pela extinta Divisão de Diversões Públicas paulista, e as pesquisas que estão sendo desenvolvidas a partir de sua documentação. Uma delas dedica-se ao estudo das relações entre censura, teatro e indústria cultural no Brasil e em Portugal, tema desenvolvido no trabalho.

O discurso televisivo em suas relações com os estudos de recepção norteia o artigo de Fernanda Budag, que busca trabalhar as questões da recepção e do consumo da telenovela Rebelde e do grupo musical $R B D$ por parte de jovens. Apresentam-se alguns resultados de uma pesquisa cujo objetivo é identificar os valores em Rebelde e contrastá-los com os percebidos pelos receptores, com a intenção de compreender as ressignificações efetuadas por estes sujeitos. Neste processo, procuram-se detectar as singularidades das identidades dos jovens receptores pesquisados, assim como as peculiaridades das práticas de consumo inseridas neste circuito. Uma vez mais, questões relativas a modos de representação e construção de identidades sociais faz-se presente.

Três artigos tematizam os discursos jornalísticos contemporâneos em suas diferentes formas de manifestação. A relação de interdependência entre jornais e assessorias de imprensa, de modo a identificar as possíveis causas para o uso cada vez mais premente de releases como fonte única para a confecção de matérias jornalísticas, é tratada no artigo de Adriana Santana. Para isso, apresenta os limites éticos da relação entre jornalistas de redação e assessores, ao mesmo tempo em que realiza um estudo de caso para esmiuçar com qual intensidade uma assessoria tem influenciado as pautas e textos dos jornais. Esse paralelo permite à autora chegar ao conceito de "jornalismo cordial" - uma subversão da atividade, realizada de modo pouco combativo e sem compromisso prévio com a apuração.

Relacionando as teorias do jornalismo, a ética da comunicação e conceitos sociológicos à análise discursiva das mídias, o jornalismo volta a ser destaque no artigo de Alexandre Augusti, em que são analisadas 22 reportagens de capa da revista Veja, sobre comportamento, para definir os principais valores que a revista destaca como centrais para nortear o comportamento contemporâneo. O objetivo é responder como Veja constrói comportamentos contemporâneos e institui sentidos sobre os valores que os norteiam. Para isso, são mapeados os valores dominantes representados nas matérias, identificando as marcas discursivas desses 
valores e como elas constroem um efeito de paráfrase ao longo de textos diversos, defendendo um indivíduo saudável, belo, inteligente e que viva com prazer.

Do questionamento sobre o discurso do apresentador José Luiz Datena, do programa Brasil Urgente, da Rede Bandeirantes, provém a utilização do suporte metodológico da análise de discurso de linha francesa para a reflexão sobre uma edição do programa. A autora, Michele Negrini, aponta que Datena, durante a apresentação do programa, tem uma postura opinativa, capaz de analisar e julgar as atitudes das autoridades competentes e os acontecimentos da sociedade. No decorrer do Brasil Urgente, o apresentador enfatiza ao público as suas opiniões acerca dos fatos e expõe os detalhes mais íntimos da vida das pessoas envolvidas nos casos apresentados, relacionando marcadamente sua audiência com as histórias contadas.

Finalmente, os três últimos artigos da edição tratam de discursos presentes nas mídias digitais. O primeiro deles, de Mariana Della Dea Tavernari, apresenta os diários virtuais como elementos-chave para compreender a articulação das profecias otimistas e pessimistas em consequência da emergência de novas mídias e formatos no mercado de comunicação nacional. Sob a ótica da remediação, apresentam-se como uma alternativa à unilateralidade imposta pelos meios tradicionais. Ao introduzirem uma narrativa expressiva similar ao jornalismo literário, aportada no ambiente bilateral e interconectado da internet, os diários virtuais tornam-se os alvos principais dos entusiastas que idealizam a concretização do chamado jornalismo cidadão.

Articulando as questões da produção discursiva das mídias em suas relações com a cultura contemporânea, Vanessa Reis apresenta, em seu artigo, uma contextualização histórica para situar o movimento pró-anorexia e pró-bulimia difundido na internet como um dos fenômenos característicos da cultura contemporânea, em muito pautada pela velocidade dos fluxos de informação e pela organização em rede. Partindo de um mapeamento cronológico da internet, o trabalho realiza a descrição do movimento próana e pró-mia - através de pesquisa empírica em diversos sites e comunidades virtuais -, e desenvolve uma análise deste fenômeno enfatizando sua relação com a rede e a cultura que proporcionaram seu desenvolvimento e expansão.

Destacando o videoclipe como formato privilegiado para pensar a produção cultural contemporânea em suas relações com a internet, o artigo de Marcelo Conter e Suzana Kilpp aborda duas temáticas do videoclipe: sua recente autonomização dos modelos de produção e distribuição da indústria fonográfica e seus devires audiovisuais, Entender a autonomização - causada pela expansão da produção videográfica para a internet - só é possível a partir da compreensão desses devires - que podem ou não se atualizar em novos videoclipes, especializando sua linguagem. Para estabelecer tais articulações, o artigo toma como referencial teórico pensadores que tratam de temas tais como tempo, percepção e memória, além de apontar aspectos da produção audiovisual e musical em sua perspectiva técnica, estética e filosófica. Também trata de esclarecer alguns aspectos da canção popular e da história do videoclipe, e de como imagem e música nele se articulam, 
retomando um dos temas recorrentes nesta edição: a produção de imagens nas mídias contemporâneas e a construção de identidades sociais a partir dessa produção.

A seção de "Resenhas" traz a leitura precisa do livro Linguagem e discurso: modos de organização, de Patrick Charadeau, estabelecendo um eixo conceitual e teórico a partir do qual torna-se possível relacionar as diversas perspectivas trazidas pelos artigos aqui publicados.

Com este segundo número, esperamos continuar contribuindo para o estabelecimento de um debate multiforme e pluralista sobre os campos de estudos privilegiados por RUMORES.

Rosana de Lima Soares Julho 2008 